\title{
Mobile Pooling and Tracking Order Application for Finance Company
}

\author{
Hanny Fauzia ${ }^{1}$ \\ Tjong Wansen ${ }^{2}$ \\ President University \\ Bekasi, Indonesia \\ 1HannyF@gmail.com \\ wansen@ president.ac.id
}

\begin{abstract}
One of the spearheads of finance companies is marketing. Marketing is usually involved directly with customers or suppliers. Things that are usually done by marketing finance companies that enter data order or customer into the system. This system is usually only accessible through computers and corporate networks. The paper proposed the development of such a system on mobile platform so that it can be easily accessed by the users. This application will be very helpful for the marketing of finance companies in providing services to suppliers or customers. Because with this application, marketing can see the order that has been entered and already the extent of the process through their smartphones.
\end{abstract}

\section{Background}

Increasing the need to access information more quickly and accurately make finance companies have to innovate in technology. Currently, the smartphone becomes one of the advances in information technology. Almost everything that can be done on a laptop / computer can now also be done by a smartphone. Even today almost everyone uses smartphones to help with their daily activities such as communicating with relatives, transacting through m-banking, shopping and opening documents.

Currently there are many finance companies whose systems are still desktop based, so when employees want to access data or information then they must go to the office first to get the desired information. This becomes a problem when the employee is away from the office. Along with the development of smartphone technology today, an opportunity for finance companies to create mobilebased applications. With the mobile based application, users can access the information needed to more quickly without the need to open your laptop or turn on the computer first. When employees of a finance company are away from the office, they can still do their work like pooling orders and check order status as long as they are connected to an internet connection.

With the various problems stated above then made an application that allows users / employees of finance companies to do their work when they are away from the office.

\section{Scope and Problem Limitation}

The scope and limitations of the problems contained in this final project are as follows:

1) This application is an application used in mobile device platform.

2) This application has 3 main functions namely:

a. Pooling order (Entering order data).

b. Tracking order (Checking the status of an order based on the order id).

c. Distribute order (Distribute new order to Field Verifier for consumer to verify).

3) Users who can use this application are employees of finance companies with positions CS (Counter Sales), COC (Credit Order Clerk) and CSH (Credit Section Head).

\section{Development Method}

For build and develop this application, RAD is chosen for the development methode, RAD contains of the simmiliar steps with SDLC, which are planning, design, coding, and implementing.

\section{Business Process Analysis}

These are the explanation of business process analysis for Mobile Pooling and Tracking Order Application:

1) User can do pooling order through application.

2) Users who can access the distribute order menu can distribute orders to Field Verifier.

3) Users can check list order from every dealer and certain date period. 
4) Users can search order status using id order.

5) Users who can access the user register menu can register users, so that the user can access the application.

\section{Application Program}

Mobile Pooling and Tracking Order Application for Financing Company is expected to show:

1) New Order page for pooling order (entering new order data).

2) Distribute Order page to distribute order to Field Verifier.

3) List Order page to do order search by dealer and in time period.

4) Tracking Order page to search status and detail of an order based on the order id in input.

5) Register User page to register users so that users who have been registered can access this application.

\section{Application Testing}

Testing is done to ensure that every function in the application is running properly. Some of the tests done are as follows:

1. Make sure each page can display according to the menu in the direction.

2. Ensure that data entered by the user is valid and in accordance with the needs.

\section{Application Testing}

From the testing that has been done by the user, it can be concluded that the overall function of the application to run as it should be.

\section{Conclusion}

Based on the results of analysis, development, and application testing it can be concluded as follows:

1. Mobile Pooling and Tracking Order Application can facilitate employees of finance companies in doing pooling order and check the status of the order remotely.

2. Data on this application has been integrated well because it can display data data in accordance with the requested.

3. Internet connection becomes one of the main factors that are important enough for this application can run optimally.

\section{References}

[1] Arisandi Ambarita, Muharto, Muhdar Abdurrahman, Faisal Kamran. Komputer : Merakit, Menginstall dan Menggunakan Microsoft Office. Sleman: Deepublish,2016,p. 18.
[2] Judy Strauss, Raymond Frost. E-Marketing. Prentice Hall,2012.

[3] Mobile Marketing Association. "MMA Global" [Online]. (http://www.mmaglobal.com/, diakses pada Oktober 2017)

[4] Pousttchi, Key. Handbook of Research on Mobile Marketing Management. IGI Global,2009

[5] Suliyanto. Electronic Theses \& Dissertations Gadjah Mada University. [Online].( http://etd.repository.ugm.ac.id, diakses pada Oktober 2017)

[6] Asosiasi Penyelenggara Jasa Internet Indonesia. "Survey Internet APJII 2016". [Online].( https://apjii.or.id/content/read/39/264/Survei -Internet-APJII-2016, diakses pada September 2017)

[7] Wikipedia."Sistem Operasi Android". [Online].( https:// id.wikipedia.org/wiki/ Android (sistem_operasi), diakses pada Oktober 2017)

[8] Android Developer. "Android Developer Dashboard". https://developer.android. com/about/dashboards/index.html, diakses pada Oktober 2017)

[9] Slinkov, Dmitriy. Mobile App for Business Up. Soloten, 2014.

[10] Muhammad Ikhsan.Academia. "Isi Tracking".[Online].( https://www.academia.edu /5150556/Isi_Tracking, diakses pada Oktober 2017)

[11] Suliyanto. Electronic Theses \& Dissertations Gadjah Mada University. [Online] .( http://etd.repository.ugm.ac.id, diakses pada Oktober 2017)

[12] Kadir, Abdul. Aplikasi Database MySQL Delphi.Yogyakarta: CV Andi Offset.2006

[13] Kim, Jin. App Marketing, This is Real Android Marketing.: IT Magnet, 2014.

[14] Information Resources Management Association. Marketing and Consumer Behavior: Concepts, Methodologies, Tools, and Applications. s.l. : IGI Global, 2014.

[15] Asosiasi Penyelenggara Jasa Internet Indonesia. ISPARMO.WEB.ID. [Online]. (http://isparmo.web.id/2016/11/21/datastatistik-pengguna-internet-indonesia-2016/, diakses pada September 2017)

[16] Information Resource Management Association. E-Marketing: Concepts, Methodologies, Tools and Application. IGI Global, 2012. 
IT FOR SOCIETY, Vol. 05, No. 01

ISSN 2503-2224 